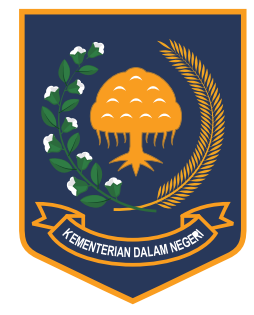

Jurnal Bina Praja 9 (2) (2017): 335 - 343

Jurnal Bina Praja

e-ISSN: 2503-3360 | p-ISSN: 2085-4323

Accreditation Number

735/AU2/P2MI-LIPI/04/2016

http://jurnal.kemendagri.go.id/index.php/jbp/index

\title{
DeVelopment of InNOVATion Project AS THE RESULT OF LEADERSHIP TRAINING Through THE InNOVATION ACTOR COLLABORATION MODEL IN THE REGION
}

\author{
Hari Soesanto * \\ BPSDM of DKI Jakarta Province \\ Abdul Muis Street No. 66, Central Jakarta, DKI Jakarta
}

Received: 6 October 2017; Accepted: 10 November 2017; Published online: 28 November 2017

DOI: $10.21787 /$ ibp. $09.2017 .335-343$

\begin{abstract}
This study is motivated by the change project's sustainability problem based on the study of PKP2A II LAN (2016) study team, identified after Level IV and Level III Leadership Training (Diklatpim). After the training, there are still some milestones or goals of the projects that have not been achieved. Medium-term and long-term goals have not been assessed because the new Diklatpim only review the general implementation of change projects during the training session. The change projects produced in the process of Diklatpim to achieve short-term goals may have a prospect to be expanded, enabling it to maintain its sustainability and to provide benefits for the region especially in the provision of public services. The current conditions rely solely on the alumni of Diklatpim and their mentors, which makes it somewhat difficult to maintain the sustainability of the change projects effectively. This study aims to provide an alternative policy solution for regional governments to improve the sustainability and increase the scale of the Diklatpim's change projects. Using literature study methods and qualitative approach, a collaborative model of innovation actors in the regional government for the development of innovation projects is developed. The collaborative model resulting from this study is called the WPPPA Model. This model is a collaboration model between Widyaiswara, Researcher, Planner and Diklatpim Alumni. The successful collaboration process undertaken by key innovation actors will be useful to maintain the sustainability of change projects on a broader scale and increasing the outcome of regional innovation sourced from the change projects.
\end{abstract}

Keywords: Project of Change, Innovation, Training, Collaboration

\section{INTRODUCTION}

This study is about the expansion of Level IV and Level III Leadership Training (Diklatpim) change projects through a collaborative model of innovation actors in the region. The Diklatpim change project is an innovation project designed and implemented by Diklatpim participants to provide solutions to the problems under their scope of duties and positions. The collaborative model of innovation actors in this study is a model involving regional government's officials who is relevant and have the competence related to the innovation project in the region.

\section{A. "Diklatpim" System}

Based on Regulation of the Head of National Institute of Public Administration Number 19 of 2015 on Guidelines for Implementing Leadership Education and Training Level III and Regulation of the Head of National Institute of Public Administration Number 20 of 2015 on Guidelines for Implementing Leadership Education and Training Level IV, one of the primary output of the Diklatpim is a change project generated through the training process in the classroom and outside the classroom, this is known as the New Diklatpim. The Old Diklatpim is Diklatpim before the year 2013, no requirement for change project and participants stays in the classroom during the training process.

\footnotetext{
* Corresponding Author

Phone : +6283813334726

Email : harisemesta@gmail.com
} 
The strategic principles in the implementation of the New Diklatpim are innovation, participation, and collaboration. Innovation is implemented in a planned and systematic way to achieve greater outcomes, greater benefits, greater impacts, costeffective, lesser risk, lesser resources and greater performance.

The learning process at Diklatpim level IV and level III consists of 5 (five) learning agendas which are: (1) Self Mastery (2) Organizational Change Diagnosis, (3) Innovation, (4) Effective Team, and (5) Change Project. The five agendas are conducted through 5 (five) learning stages which includes:

1. Organizational Change Diagnostic Stage, consisting of 4 (four) learning agendas which are: some material from Innovation agenda, all content of Self Mastery agenda, all material of Diagnostic of Organizational Change agenda and some content from Change Project agenda. The product of this stage is the individual identification of the problem area. This activity is on campus;

2. Joint Commitment Stage, consists one agenda, the change project. The product of this stage is a shared commitment between participants and stakeholders to enact changes to a particular problem area. This activity is off campus;

3. Change Design and Team Building Stage, consisting of 3 (three) learning agendas namely: Innovation agenda, Effective Team agenda and some material from Change Project agenda. The products are Change Project design and map of potential stakeholder. This activity is on campus;

4. Leadership Laboratory Stage, consisting of Change Project agenda. Its product is Implementation of the change project. This activity is off campus;

5. Evaluation Stage consisting of Change Project agenda. Its product is a project implementation report of the change project that has been evaluated and shared with other participants. This activity is on campus.

The overall stage is designed to create change leaders as evidenced by the change projects generated by each participant.

The Change Projects produced by the fourth level Diklatpim participants for echelon IV officials and Diklatpim level III for echelon III officials in the regional government.

1 (one) class of Diklatpim consists of 30 (thirty) participants, producing at least 30 (thirty) Change Projects. Implementation of the change projects would have a positive impact on public service improvement of the regional government even if only some of the ideas or change projects are sustainable in the long run.

Budiati (2016) stated that the new Diklatpim is aimed to create bureaucratic leaders with an adaptive leadership, able to encourage and mobilize others in the organization and to lead their organization to be adaptable to change by continually innovating and collaborating.

Wahyudianto (2015) stated that public service activities by the government are inevitable, a necessity, in which people expect a higher quality of government, providing a better public service, community empowerment, and socio-economic development.

Through the optimization of the government functions (mainly the public service functions), people may expect a broader sense of justice, a higher level of independence in developing themselves and solving problems, and improving their welfare. If these expectations are realized, the people will be satisfied with the services provided by the government as the public servant.

In line with the above expectation, the Diklatpim's Change Projects is produced to fulfill the public need.

\section{B. Collaboration and Innovation}

Collaboration is believed to be a useful model for the enhancement of the Diklatpim's Change Project. The problem of collaboration in the regions is also related to coordination problems between the Regional Working Unit (SKPD). This is in line with Kartika's research (2017) which suggests that one of the elements of regional innovation system is the regional government (through regional government budget), supportive innovation policy and coordination between SKPD and other parties. In addition to Kartika, Putera (2012) shows that one of the instruments of science and technology and innovation policy is through the practical technology communication forum.

To date, there is no known forum established by the regional government related to the enhancement of post-Diklatpim change projects.

Continuous innovation and collaboration by forming networks amongst the participants during the Diklatpim is indeed a must. Post-Diklatpim it is challenging to continue the innovation and collaboration by relying only to the alumni. A collaboration model that can offer solutions for Diklatpim alumni to continue their innovation effort to provide a better public service and regional development need to be established.

There are different timelines for the goal of the change projects, which are: short-term (one month), medium-term (one year) and long-term (more than one year). Participants of Diklatpim of the regional government are from various SKPD. They implement their short-term change project or 
following the duration of the Diklatpim. In general, the change projects generated by participants are mostly to ease the public in accessing their SKPD's services.

Post-Diklatpim, the medium/long term change projects are difficult to sustain if it only relying on the alumni. The sustainability of the medium/long term change projects has to be ensured to reap more benefit for the public.

Change projects implemented by more and more regions will have an impact on increasing innovation at the national level, which in turn affects national competitiveness. The WEF (World Economic Forum) (2017) classifies 12 pillars of competitiveness as follows (1) institutions, (2) infrastructure, (3) macroeconomics, (4) health and basic education, (5) higher education, (6) market efficiency goods, (7) efficiency of the labor market, (financial markets), (9) technological readiness, (10) market size, (11) business sophistication, and (12) innovation.

An approach to achieve the long-term goals of a change project and reap a greater benefit for the public is by developing a collaborative model among key innovation actors in the project. This paper offers a collaborative model of innovation actors in the region for the sustainability and development of the change project, to achieve the intended purpose as described earlier.

Most innovative ideas do not become successful new products. Many studies reveal that only one of several thousands of ideas produce a successful new product. One successful new product requires 3,000 raw ideas. This process of innovation is described by Schilling (2015) as a funnel, where many new potential product ideas enter a wide end of the funnel, but very few have made it through the development process.

Furthermore, according to Schilling, to increase the success rate of an organization's innovation required a well-structured strategy. Adopting what Schilling states, regional governments requires (a) an in-depth understanding of the dynamics of innovation, (b) a well-crafted innovation strategy, and (c) processes that well designed to implement the innovation strategy, to create successful innovations in provision of public services. All of these basic needs can be accommodated through a collaborative model.

Based on Schilling (2015), different types of innovation require different types of basic knowledge and have different impacts on competitors and users. The four most common dimensions used to categorize innovations are as follows: (1) product innovation versus process, (2) radical versus incremental, (3) increasing existing competence versus destroying existing competence, and (4) architectural versus component.

\section{Product Innovation versus Process} Innovation. Product innovations are manifested in the outputs (goods or services) of an organization. Process innovations are innovations in the business operations of the organization. Process innovation is often directed at increasing the effectiveness or efficiency of the production processes. Product innovations and process innovations often go hand in hand. Although product innovations are often more visible than process innovation, they are extremely important to the competitiveness of an organization.

2. Radical Innovation versus Incremental Innovation. Radical innovation is a very new and different innovation from existing practices/products. Incremental innovation is an innovation that results in minor changes from (or adaptation) to existing practices/ products.

3. Competence Enhancing Innovation versus Competence Destroying Innovation. Innovation can be built on (or cause obsolete) of existing knowledge or expertise. Whether an innovation is enhancing or destroying competencies depends on the perspective of an organization. Innovation can be competence enhancing to one firm but competence destroying to another. Innovation is considered to be damaging to competence from the perspective of a particular organization if the technology is not built on the existing competencies of the organization or cause such competencies to become obsolete.

4. Architectural Innovation versus Component Innovation. Most products and processes are hierarchically arranged systems, that an entity is a system of components, and each component is, in turn, a system of smaller components, until we reach a point where these components are the basic particles. Component (or modular) innovation is an innovation on one or more components that do not have a significant effect on the overall configuration of the system. While architectural innovation is an innovation that changes the overall design of a system or the way in which its components interact with each other.

\section{Issues Post Diklatpim}

Identified problems related to the change projects after the Diklatpim training, among others; sustainability, lack of collaboration, financial support, and synchronization with the planning documents. The main issues discussed in this study are the sustainability and the enhancement of the change projects. This is in accordance with the conclusions of a study by PKP2A II LAN (2016) 
that there is a sustainability problem with change projects after Diklatpim is concluded.

Mukhlis (2016) reviews the results of Diklatpim Level IV (Pringsewu District, Lampung Province as the case study) and found that the change projects generated by the participants of Diklatpim IV still revolves around optimizing efforts, not development efforts. Innovation emerging from echelon IV officials also revolves around administrative optimization which is very likely already being mandated in the technical regulations issued by the central government. The change projects in Diklatpim IV are more of individual creativity in running their unit, not a leader's innovation that might become the driver of the emergence of regional innovation. Based on the results of the research, there is a need for the expansion of change projects to lead to a broader scale of regional innovation.

Meanwhile, according to Rusmulyani (2015), after completion of Diklatpim, the alumni would like to develop their innovations projects. This needs to be followed up.

This study is conducted to accommodate the alumni's motivation to develop their innovation project further and to provide the means to do so. Regional Government's human resources and the alumni of Diklatpim are the sources in developing the collaborative models. The focus of the study includes an understanding of change projects, innovation actors in the region, collaboration models between innovation actors and the benefits of the resulting collaborative model.

\section{MeThod}

This study was conducted from August to October 2017 by using library research of scientific papers produced by previous researchers, in various perspectives based on relevant theories and concepts. Through scientific papers of various researchers and expert opinions, an interpretation to formulate conceptions about the fact being studied can be obtained. The interpretation and formulation of the concept are conducted using a qualitative approach.

A qualitative approach used is to present the concept and the underlying reason of the proposed model for the enhancement of change projects as an alternative solution to problems identified earlier in this paper. Through qualitative approach, the data collected in the form of a description- words, images, and not numbers. The qualitative approach uses inductive data/information analysis and more concerned with the "process" rather than "outcome".

In the implementation section, the collaborative model adopts the actor-network theory (Teori Jejaring Aktor/TJA) as conducted by Priyatma (2013). Priyatma (2013) points out the potential of TJA to understand technological innovation. In this theory, the results of technological innovation activities are seen as the result of a network involving both technical and social actors. Both types of actors are assumed to have the same contribution to network building. Whether the network will eventually develop and becoming useful depends on the strength of the relationships between actors, that are heavily influenced by the advantages and disadvantages that the actors will gain in the network. Based on TJA, in the context of Diklatpim change projects the relationship between innovation actors who will be involved in the development process are very important.

Based on the TJA, there are 4 (four) stages of TJA:

1. Problematization. At this stage, one or more key actors formulate the problem and define the role of other actors in solving the problem. The solution is then proposed to the involved actors so that they are bound to a centralized control mechanism called the "obligatory passage point (OPP)."

2. Interessement. At this stage, all the actors identified in the first stage are given specific roles and identities to attract them to engage in the network and the programs/activities offered.

3. Enrollment. A successful program/activity to attract the relevant actors to be involved in a problem resolution will result in the actors' commitment to be part of the alliance network. The enrolment process is a success when many relevant actors eventually join this network.

4. Mobilization. Once a proposed solution gets the support it will form a bigger and stronger alliance which involves other actors indirectly. If this happens then, the process of mobilization has been going well.

\section{RESULTS AND DISCUSSION}

\section{A. Sustainability of Change Projects}

The implementation of the change project using the current model, which focused on the alumni, cannot guarantee the achievement of longterm goals or long-term benefits of the change project. This is in accordance with the study result from the PKP2A II LAN (2016), which stated that the implementation of the change project of Diklatpim III does not continue to the medium and longterm goals. Existing targets on medium- and longterm goals cannot be realized due to the lack of an effective team to implement the change projects, both internally and externally.

Based on Law of the Republic of Indonesia Number 23 of 2014 on Regional Government and Government Regulation Number 38 of 2017 on 
Regional Innovation, innovations are all forms of renewal in the implementation of regional government. Within that context, the Diklatpim change projects are an innovation.

With the issuance of the Minister of Research and Technology \& Minister of Home Affairs (2012) and Law of the Republic of Indonesia Number 23 of 2014 on Regional Government where regional innovation is stipulated in its own chapter, there is a strong foundation for the region to improve innovation in their respective areas. Suhendra (2017) states that innovation stipulated in Article 386 in Law of the Republic of Indonesia Number 23 of 2014 on Regional Government is any form of regional government reform. Innovation is referred to an idea, practice or object that is considered new by the individual. Innovations can be new products or services, new production technologies, new structural and administrative systems or new plans for members of the organization. Innovation in the public sector is a way or even a breakthrough to overcome congestion and organizational deadlock in the public sector. Public sector characteristics that are rigid and inclined to favor the status quo should be changed through the spread of an innovation culture. Innovation that are usually only familiar in dynamic environments such as the business sector are slowly beginning to be injected into the public sector. Innovation is gaining ground in the public sector. This is inseparable from external dynamics and the rapid demands of changes that occur outside the organization, changes in society with better literacy levels and better awareness of the people regarding their rights. Thus, the public sector can be a sector that can accommodate and respond quickly to any changes that occur.

In accordance with those regulations, the Diklatpim change projects is an innovation, an ongoing activity that needs to be developed to achieve short, medium and long-term goals to meet the needs of the public. Taufik (2005) argues that innovation allows improvement of the system that leads to improvements in people's lives. Awareness of this fact needs to be updated continuously. Hargadon \& Sutton (2000) argue that most innovations are not a discovery, but are the result of recombination of existing concepts and materials.

In the innovation process, there is a creation of added value. Utomo (2016), stated that value creation is the act to increase value to users and related parties. Public service improvement is achieved through improved change and innovation which is preceded by improved leadership training.

According to Utomo's opinion, the phase of improved change and innovation is a step that must be conducted to achieve improved public service stage. The current post-Diklatpim model is in need of a breakthrough that can involve other relevant resources. The breakthrough is the phase of improved change and innovation.

Although many expert opinions on innovation are mostly in the private sector, innovation in the public sector is essentially no different from the notion of innovation in the private sector, because it is undeniable that the economic benefits of innovation are also needed by the public sector to develop itself as in the private sector, unless if it involves social issues (Mulyono, 2008).

\section{B. Identification of Potential Innovation Actors}

The government has a significant role in the development of public service and public policy programs. Various regulations and regulations concerning public service organizations must, of course, be formulated by considering the public needs. The responsibility of the government is not just to create and run programs of economic value but more importantly identifies whether the programs and policies are in accordance with the public needs and not limiting their productive creativity (Wahyudianto, 2015). This means that the primary actor who plays a major role in public service is the government. Government resources related to an innovation of public services in regional government are, among others, administrative officials who have the task to control government programs in accordance with their primary duties and functions.

Currently the main actors in the Diklatpim change projects are trainees who are mentored by Mentor (direct supervisor) and Advisor (Widyaiswara), starting from the commencement to the end of the Diklatpim. After the Diklatpim training, the sustainability of the change project becomes the alumni responsibility. Such situations potentially may cause the proposed change project to be unsustainable, since to achieve the long-term goal of the change project, a funding scheme as well as a change project enhancement model that is continuously updated in accordance with the public's needs is required, not only the involvement of the Diklatpim alumni. While there are other innovation actors in charge of performing their respective jobs in different places, but they have not been connected/involved directly with the Diklatpim's alumni change projects.

Referring to Law of the Republic of Indonesia Number 5 of 2014, the role of State Civil Apparatus ("Aparatur Sipil Negara/ASN") is a planner, executor, and supervisor of the general task of government and national development. Soesanto (2016) stated that concerning the potential of innovation initiation or development in regional government, ASN actor is the most potential actor to be able to introduce and develop innovation in the region. Some ASN in the 
Table 1.

Identification of Potential Innovation Actors in Regional Government

\begin{tabular}{lcc}
$\begin{array}{c}\text { Innovation } \\
\text { Actor }\end{array}$ & SKPD & Task \\
Researcher & $\begin{array}{c}\text { Balitbangda/ } \\
\text { Bappeda }\end{array}$ & $\begin{array}{c}\text { Research and } \\
\text { Development }\end{array}$ \\
\hline Planner & Bappeda & Planning \\
\hline Widyaiswara & BPSDM/ & $\begin{array}{c}\text { Educate, } \\
\text { Teach and } \\
\text { Training Unit } \\
\text { and Develop } \\
\text { Training }\end{array}$ \\
\hline $\begin{array}{l}\text { Diklatpim } \\
\text { Alumni }\end{array}$ & SKPD/UKPD & $\begin{array}{c}\text { Implement the } \\
\text { Change Project }\end{array}$ \\
\hline
\end{tabular}

regional government environment has an element of innovation in their functional positions. Some of them are researchers, planners, and widyaiswara.

Within the regional government, researchers are usually assigned to the work unit of the Regional Research and Development Agency (Balitbangda). The planner is assigned to the work unit of the Regional Development Planning Agency (Bappeda). In one area, Balitbangda and Bappeda are even in one unit. The Widyaiswara is on the Human Resource Development Agency (BPSDM). The researchers, planners, and widyaiswara are all performing innovations in conducting their functions, but they are not connected to a network. The identification of potential innovation actors in the regional government environment relevant to the change project is presented in Table 1.

Based on Table 1. Although the competence and duties of each actor are very relevant to the content of the change project, the potential innovation actors from ASNs in the regional government have not been consolidated in any specific schemes for the development of a joint innovation, or the Diklatpim change projects.

The opportunity for innovative cooperation in the form of change projects that generated by the Diklatpim alumni in regional government is important because if the change projects are developed further with the appropriate model, it will be able to produce successful innovation, an innovation that can help accelerate development of public services in the region.

Hartiningsih, Hermawati, Maulana, \& Rosaira (2014), stated the importance of networking roles among actors in the field of energy as a knowledge sharing means and information center for required technology, techniques, and methods, on the search for experts in the field, and dissemination to the wider community. The most dominant role of the actors in sustaining the renewable energy technologies is to maintain the alignment of interests to keep the technology in its high-performance level.

\section{Collaboration Model between Innovation Actors}

Collaboration is a form of social process, in which there are specific activities aimed at achieving common goals by helping each other and understanding each other's actions (Abdulsyani, 1994). According to the official dictionary of the Indonesian language, The Great Indonesian Dictionary (KBBI), collaboration is cooperation.

Collaboration is a form of cooperation, interaction, compromise of several elements related to individuals, institutions and/or parties involved directly and indirectly who receive the consequences and benefits. The values underlying a collaboration are common goals and perceptions, willingness to process, mutual benefit, honesty, compassion and community-based approach (Haryono, 2012). Haryono further explained that the bureaucracy problems and high public demand for quality public services requires a new governance model. The current hierarchical government bureaucracy being utilized to provide public services and efforts to achieve public policy goals need to transform to a form of government networks as the new form of governance.

In the business world, companies often form partnerships with customers, suppliers, and even competitors to work together in an innovation project or to exchange information and other resources for innovation. Collaboration can occur in the form of unions, participation in a research consortium, licensing agreements, research and development agreements, joint ventures, and other arrangements of cooperation. The most frequent collaboration is between companies and their customers, suppliers, and regional universities (Schilling, 2015).

Collaboration is more than coordination, although in reality sometimes it is still difficult to establish a simultaneous and continues coordination between the Regional Work Unit (SKPD). Therefore, change agents or key innovation actors in areas with relevant functional tasks on innovation need to be involved and supported through appropriate collaborative models.

The current project implementation model is relying on the Diklatpim's alumni (SKPD) supported by their supervisor (their mentor). If the alumnus is a supervisory officer (echelon IV) then generally his mentor is an administrative official (echelon III). Whereas if the alumni are administrative officers, then the mentor is a pimpinan tinggi pratama official (echelon II). There is no standardized model of postDiklatpim collaboration in the regional government 
although the potential is quite significant.

The Regional Government Work Unit (SKPD), in this case, the Diklatpim alumni, often have difficult decisions about the scope of change projects activities to be conducted within the SKPD or Regional Government as a whole. The development effort to scale-up the change projects for strategic impact would be better if it involves other innovation actors. Schiling (2015) mentions that collaboration can often allow companies (in this case the SKPD) to have better achievements, faster, and operate at lower costs and risks than they may have by its own. Kardoyo \& Dolant (2009) stated that of R \& D networks can be achieved through various forms of organization, both formal and informal, that can connect the innovation actors.

Currently, the implementation of the change projects only involves the alumni and the widyaiswara. As mentioned earlier in the introduction, it caused a problem in the form of the sustainability of the change project, the limited scale and time to reap the benefits.

There is no definitive formula on how to develop innovation in the public sector. To be innovative, the public sector can develop its own innovative concepts. It can be developed, implemented and managed in accordance with their existing needs and conditions (Mulyono, 2008). Thus, the regional governments need to develop the models or means to develop innovation in their regions.

The proposed collaborative model as one of the alternative solutions for the development of post-Diklatpim change project is the WPPA Model, which is a collaborative model between the alumni of Diklatpim, Widyaiswara, Researcher, and Planner. The ultimate goal is the realization of regional innovation in accordance with Law of the Republic of Indonesia Number 23 of 2014 on Regional

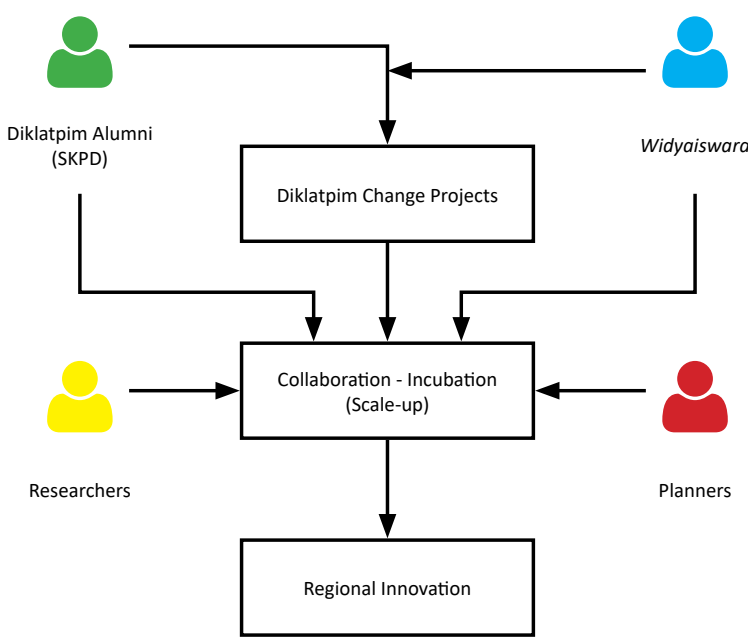

Figure 1. Collaboration Model of Widyaiswara, Researcher, Planner, and Alumni of Diklatpim (WPPA Model) for Enhancement of Diklatpim Change Projects
Government and Government Regulation Number 38 of 2017 on Regional Innovation (Figure 1).

The model adopts the TJA theory (Priyatma, 2013), where its implementation is based on 4 (four) stages namely Problematization, Interessement, Enrollment, and Mobilization.

1. In Problematization stage, potential innovation actors who have been identified are widyaiswara, researchers, planners and alumni of Diklatpim formulate issues related to their respective functional tasks and their relevance to the development of innovative projects to increase the impact and scale of the change project for the region.

2. At the Interessement stage, innovation actors who have been identified in the initial stages are given their specific roles that are made as attractive as possible to attract the potential actors to be involved optimally in the development of the change project. The role of each actor can be stated as follows:

- Diklatpim Alumni (SKPD): represents their SKPD to supply information regarding barriers and updates on the public needs to the project changes that have been conducted in the previous stage

- Widyaiswara: screens change projects to select the ones tha to be developed further, as well as being team facilitator (Model WPPA)

- Researcher: using the scientific method for development of change projects according to their field of expertise.

- Planners: synchronize change projects activities with the RPJMD (Regional MediumTerm Development Plan) to ensure that the change projects sustainability is in line with RPJMD.

3. At the Enrollment stage, the innovation actors agree on a shared commitment to the role that will be undertaken to develop the change projects.

4. At the Mobilization stage, the innovation actors consolidate the teams and build stronger and more significant alliances. At this stage, it is expected to involve stakeholders from outside of the team.

\section{Benefits of the WPPA Collaboration Model}

Collaboration is a significant factor to drive innovation. Mulyana \& Sutapa (2014), examined the Quadruple Helix collaborative approach, collaboration between government, business, academia and the public in the fashion industry's creative industry and the result of their study indicates that collaboration pushes the community's role in enhancing creativity and innovation. 
Rokhyadi (2013) finds that non-technical innovation and collaboration of innovation activities are stronger when interacting with information systems. Non-technical innovations themselves, as well as marketing innovation and organizational innovation, are treated as the organization knowledge. The employee's idea and the adoption of external information are needed to improve the knowledge and emotional bond among the employee, thereby generating togetherness and enhancing performance.

Collaboration in the development of innovative projects including the change projects generated Diklatpim alumni may provide benefits. The collaboration proposed in this paper is the collaboration of the WPPA Model, which is expected to provide the following benefits:

- Encourage the sustainability of change projects implementation to achieve medium and longterm goals after the Diklatpim training.

- Collaboration may improve the ability of the organization (SKPD) in acquiring the skills or resources faster than having to conduct it themselves. The WPPA model assist in the process of searching and utilizing selected skills and resources since the actors are functional skilled officers (Widyaiswara, Researchers, and Planners) who have the competency/expert certification

- With collaboration in the WPPA model, the SKPD would be able to reduce its workload and increasing their efficiency. The efficiency is needed since the alumni are administrative officers in the SKPD, which job is to perform their respective duties and functions in accordance to the existing regulations and their superior's assignments, not only to develop change project

- Collaboration between SKPD is a valuable learning resource for them. The intense relationship between actors in the WPPA model can facilitate the transfer of new knowledge and skills which it will not be possible otherwise.

- As the primary source of funding for the development of the change project is sourced from the Regional Government Budget (RAPBD), through the WPPA model collaboration, the sustainability prospect becomes more positive regarding financing and cost structure.

- The actors' (who are all public servants) esprit de corps and performance may increase as stated in a study by Rokhyadi (2013).

- The actors involved in the WPPA model will produce a common output, called the regional innovation. This will facilitate the emergence of a common standard in the regional government and has the prospect to become a role model or even expand its range of collaborations with other actors. Increasingly high quality and numbers of innovation will improve the competitiveness of the region and the quality of the public service.

\section{ConClusion}

This study concludes that the sustainability problem of the Diklatpim change projects to achieve the medium and long-term goals, and the expansion of the scale of innovation can be addressed through an alternative solution using a collaboration model called WPPPA Model. The WPPA model is in the form of a collaboration between Widyaiswara, Researcher, Planner and Diklatpim Alumni. The successful collaboration process undertaken by key innovation actors will be useful to encourage the sustainability of the change projects on a broader scale and to improve the output of regional innovation.

The impact if the implementation of WPPA model runs optimally at the regional and national level is that more quality innovation of the result of change projects that are produced after Diklatpim. In turn, this will be useful for regional development especially in the aspect of increasing the competitiveness of regions and improvement of public service.

Concerning the absence of a specific and regular forum regarding the development or sustainability of the change projects involving innovation actors in the regions, it is proposed that a forum should be established to facilitate the WPPA Model by a decision letter of the Regional Head to accelerate the process of developing the change project.

\section{ACKNOWLEDGEMENT}

The authors would like to thank the experts, innovation actors, and institutions that have assisted in the research and the completion of this study, mainly to BPSDM DKI Jakarta Province, Research, and Development Agency of the Ministry of Home Affairs and State Administration Institution.

\section{REFERENCES}

Abdulsyani. (1994). Sosiologi: Skematika, Teori, dan Terapan. Jakarta: Bumi Aksara.

Budiati, L. (2016). Diklat Kepemimpinan Pola Baru dalam Perspektif Inovasi dan Pembelajaran Konstruktivistik. Jurnal Pembangunan Wilayah \& Kota, 11(2), 211. http://doi.org/10.14710/ pwk.v11i2.10849

Government Regulation Number 38 of 2017 on Regional Innovation, Pub. L. No. 38 (2017). Indonesia.

Hargadon, A., \& Sutton, R. I. (2000). Building an innovation factory. Harvard Business Review, 78(3), 157-66, 217. Retrieved from http:// 
www.ncbi.nlm.nih.gov/pubmed/11183977

Hartiningsih, Hermawati, W., Maulana, I., \& Rosaira, I. (2014). Peran Jejaring dan Aktor dalam Mempertahankan Kesinambungan Energi di Perdesaan. Seri Laporan Teknis Penelitian. PAPPIPTEK-LIPI.

Haryono, N. (2012). Jejaring untuk membangun kolaborasi sektor publik. Jurnal Jejaring Administrasi Publik, 4(1), 47-53. Retrieved from http://journal.unair.ac.id/ADMP@jejaring-untuk-membangun-kolaborasi-sektor-publik-article-9496-media-81-category-8.html

Kardoyo, H., \& Dolant, S. (2009). Intensitas Jejaring Litbang dalam Sistem Inovasi Sektor Kesehatan dan Obat-obatan: Studi Kasus 12 Pelaku Industri Kesehatan dan Obat-obatan. Kebijakan Iptek \& Manajemen Litbang, 1(2), 141-156. Retrieved from http://www.jurnal.lipi.go.id/publikasi.cgi?tampilpublikasi2\&1095014210\&Indonesia\&vol=1\&1327363751

Kartika, R. S. (2017). Local Government Readiness in Developing SIDa Roadmap in Banten, West Sumatera, and Bali. Jurnal Bina Praja, 9(1), 127-136. http://doi.org/10.21787/ jbp.09.2017.127-136

Law of the Republic of Indonesia Number 23 of 2014 on Regional Government, Pub. L. No. 23 (2014). Indonesia.

Law of the Republic of Indonesia Number 5 of 2014 on State Civil Apparatus, Pub. L. No. 5 (2014). Indonesia.

Minister of Research and Technology, \& Minister of Home Affairs. Joint Regulation of the Minister of Research and Technology with the Minister of Home Affairs No 3 of 2012 and No 36 of 2012 on the Strengthening of the Regional Innovation System (SIDa), Pub. L. No. 3 \& 36 (2012).

Mukhlis, M. (2016). Menakar Peluang Munculnya Inovasi Daerah Pasca Undang-undang 23 Tahun 2014 (Studi pada Hasil Diklatpim IV Kabupaten Pringsewu Provinsi Lampung). CosmoGov, 2(1), 1-22. http://doi.org/10.24198/ cosmogov.v2i1.11848

Mulyana, \& Sutapa. (2014). Peningkatan Kapabilitas Inovasi, Keunggulan Bersaing dan Kinerja melalui Pendekatan Quadruple Helix: Studi pada Industri Kreatif Sektor Fashion. Jurnal Manajemen Teknologi, 13(3), 304-321. http:// doi.org/10.12695/jmt.2014.13.3.5

Mulyono, F. (2008). Inovasi di Sektor Publik. Jurnal Administrasi Publik, 5(2), 130-144. Retrieved from http://journal.unpar.ac.id/index.php/ JAP/article/view/1564

PKP2A II LAN. (2016). Laporan Kajian Sustainibilitas Inovasi Alumni Diklatpim III dan IV. Makassar: PKP2A II LAN.
Priyatma, J. E. (2013). Potensi Teori Jejaring Aktor untuk Memahami Inovasi Teknologi. In Seminar Nasional RITEKTRA 2013 (Riset dan Teknologi Terapan). Retrieved from https://repository.usd.ac.id/4456/

Putera, P. B. (2012). Perspektif Sistem Inovasi dalam Konten Kebijakan Daerah Jawa Timur Bidang Iptek dan Inovasi Periode 2000-2011. Warta KIML, 10(2), 83-98. Retrieved from http://situs.jurnal.lipi.go.id/wartakiml/

Regulation of the Head of National Institute of Public Administration Number 19 of 2015 on Guidelines for Implementing Leadership Education and Training Level III, Pub. L. No. 19 (2015). Indonesia.

Regulation of the Head of National Institute of Public Administration Number 20 of 2015 on Guidelines for Implementing Leadership Education and Training Level IV, Pub. L. No. 20 (2015). Indonesia.

Rokhyadi, A. (2013). Dampak Strategi Inovasi Non Teknis dan Kolaborasi Aktivitas Inovasi pada Kinerja Perusahaan. EFEKTIF: Jurnal Bisnis Dan Ekonomi, 4(1), 15-25. Retrieved from http:// jurnalefektif.janabadra.ac.id/wp-content/uploads/2015/11/Efektif-Juni-2013_2.pdf

Rusmulyani. (2015). Efektifitas Penyelenggaraan Diklat Kepemimpinan Pola Baru terhadap Kinerja Aparatur (Studi Kasus Diklatpim IV pada Badan Diklat Provinsi Bali). Jurnal Lingkar Widyaiswara, 24-51. Retrieved from http:// juliwi.com/edisipitiwi3.html

Schilling, M. A. (2015). Manajemen Strategis Inovasi Teknologi. Yogyakarta: Pustaka Pelajar.

Soesanto, H. (2016). Dukungan Regulasi terhadap Inovasi Penyelenggaraan Pemerintahan Daerah. Jurnal Litbangda, 1.

Suhendra, A. (2017). Kesiapan Pemerintah Daerah dalam Mewujudkan Kota Cerdas di Bandung dan Surabaya. Matra Pembaruan, 1(1), 1-9. http://doi.org/10.21787/mp.1.1.2017.1-9

Taufik, T. A. (2005). Pengembangan Sistem Inovasi Daerah: Perspektif Kebijakan. Jakarta: Badan Pengkajian dan Penerapan Teknologi.

Utomo, T. W. W. (2016, June 1). Leadership Training as Shared-Value Creation Process in Indonesia's Public Service System. Revolusi Mental: Creating Shared Value in Public Sector for Sustainable Innovation and Development. Jakarta, Indonesia.

Wahyudianto, H. (2015). Pengukuran Tingkat Kepuasan Masyarakat terhadap Pelaksanaan Kebijakan Pelayanan Pemerintah. Jurnal Bina Praja, 7(4), 331-345. http://doi. org/10.21787/JBP.07.2015.331-345 